\title{
IMPORTANCE OF THE ORE VEINS TO STUDY, TO INTERPRET AND TO PROTECT THE MINING HERITAGE
}

\author{
José DUEÑAS MOLINA ${ }^{1}$ \\ Marek W. LORENC ${ }^{2}$ \\ Agustín MOLINA VEGA ${ }^{1}$ \\ Francisco MOLINA MOLINA $^{1}$ \\ José Susi LIÉBANAS ${ }^{1}$ \\ Antonio Ángel PÉREZ SÁNCHEZ ${ }^{1}$ \\ ${ }^{1}$ Member of Colectivo Proyecto Arrayanes, Linares (Jaén), Spain; \\ proyectoarrayanes@gmail.com \\ 2 Member of Colectivo Proyecto Arrayanes; Wroclaw University of Environmental and \\ Life Sciences, Institute of Landscape Architecture; marek.lorenc@upwr.edu.pl
}

mining heritage, legal protection, cultural landscape, working methodology

Four thousand years of mining activity shaped a singular cultural landscape in the Linares - La Carolina district. The geological richness of the area attracted the main civilizations from different eras. Argarians, Romans, Carthaginians, as well as mining companies from Great Britain, Germany, France and Belgium during the industrial period, established their installations working the rich veins of copper and galena.

In 2002 the Cultural authorities of the Andalusia Board entrusted the Colectivo Proyecto Arrayanes with a research to identify the most significant remains. The result of our work was the documentation for the inscription of 65 mining and metallurgy sites in the Andalusia Historic Heritage List. Later, we extended the work to a second record including 60 more sites, belonging to all municipalities of the mining district.

Currently, our association is developing a project to obtain the certification of the ancient mining district as Heritage Area, a new legal body of the Historical Heritage Law published in Andalucía in 2007. This could provide better protection for the main part of the mining sites and remains in the district, including the archaeological sites. The declaration will allow the management of the territory to became a Cultural Park.

Our research establish 16 sectors, extended over eight municipalities. Each sector is related to one or several veins, and includes mining sites, archaeological sites and remains re- 
lated to metallurgy, ore dressing or railway installations. And each site is described in a registry card. We have catalogued more than 580 sites. Around 150 of them have evidences of the presence of Cornish technology.

The Cultural Landscape as axle of future developments and the veins are the real order of the mining territory. Industrial and mining remains, roads, railway lines, etc, are placed in relation with the orientation of the veins. These are the main guidelines of the Working Methodology we are developing to complete this ambitious project.

\section{Introduction}

The Linares - La Carolina Mining district makes up one of the not iron mining regions most important in the world, due to its history as well as to its intensive production. A singular mining landscape was shaped throughout four thousand years, showing the relationship between the humans and their environment and the way they adapted it to the productive activity. In a relatively small extension, there are an impressive number of mining remains that confer it a great inherited value.

In the current situation, when the area is undergoing a very difficult socioeconomic situation, with high unemployment rate and loss of population, it is very important to progress becoming the rich mining industrial heritage in a development resource for the municipalities included in the ancient mining district. An appropriate legal protection will allows the management of the district as a Cultural Park, with commons and coordinated action guidelines, to offer a solid, attractive and well-articulated cultural tourism option, helping as well to diversify the economic activity of the full region.

\section{Geological structure of the district}

The Linares - La Carolina mining district is located in the north of the Jaén Province (north Andalusia) and it extends from Despeñaperros (in Sierra Morena) ca. 40 kilometres to the south as a zone ca. 30 kilometres wide. It consists of eight municipalities: Bailen, Baños de la Encina, Carboneros, La Carolina, Guarroman, Linares, Santa Elena and Vilches. Overall, these population have 107.341 inhabitants and take up a surface of $1.480 \mathrm{~km}^{2}$.

The district is divided in two parts with different geological and morphological characteristics (Fig. 1). The southern area includes vicinities of Bailén, Linares, Vilches and Guarromán, with a countryside landscape and the Sierra Morena foothills. Biotite granite, which is a dominating rock here is also the main metalbearings rock of the area. The post-magmatic metalliferous veins cut both granite 
and the sandstone, which forms a sedimentary cover of the intrusion (Anonimous, 1877). The northern area of the district includes vicinities of Baños de la Encina, Carboneros, La Carolina and Santa Elena (Fig. 2). In this area cover of the granitic intrusion is composed of Palaeozoic medium- or low-grade metamorphic rocks, such as quartzites, phyllites, argillaceous slates. Here the metal-bearing veins also transverse both the granite and its host (IGME, 1977; 1976).

The veins morphology in all the district is almost vertical, with mineralisation in different phases. The main is a compound of lead sulphide (galena), reaches a tenor of 75 to $78 \%$ lead, and 160 to 250 grams of silver per ton. Among the gangues accompanying the sulphide and carbonate of lead, prevail quartz, barite, calcite, with much more decomposed granite or slates and clays. One also finds some blende, pyrites and iron carbonates pyromorphite, anglesite and some oxides of iron and copper near de surface (Hereza \& Alvarado, 1926).

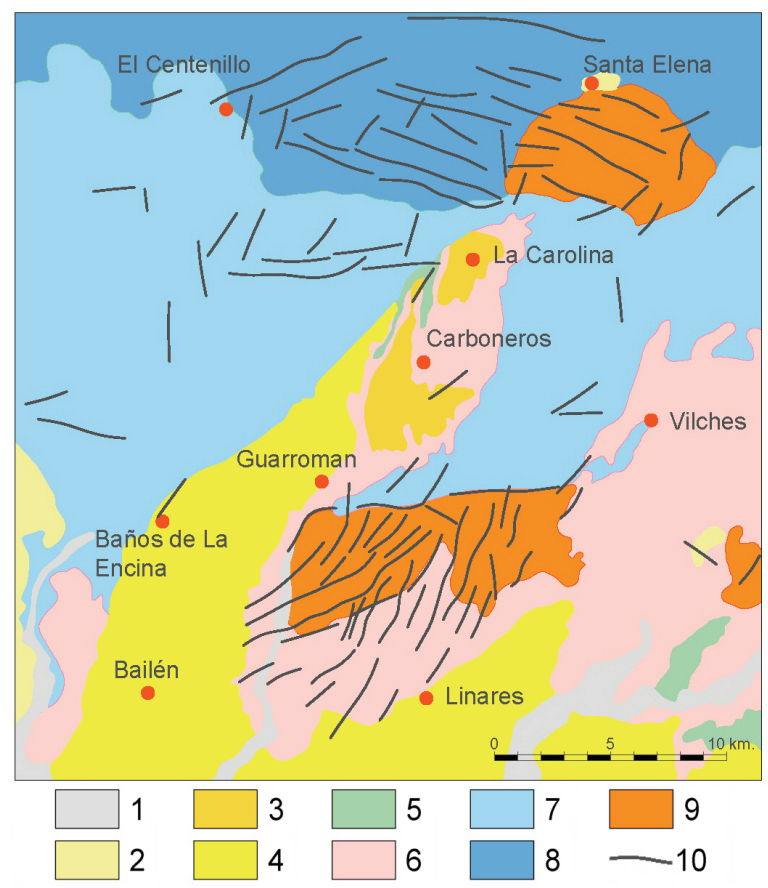

Fig. 1. Location of the main veins of the Linares - La Carolina mining district; 1 - alluvial, 2 - sands, conglomerate and clays, 3 - loam, sandstones and limestone, 4 - loam and sandstones, 5 - dolomite and loam, 6 - conglomerate, sands and clays, 7 - slates,

8 - quartzite, 9 - granite, 10 - ore vein (all pictures: Colectivo Proyecto Arrayanes)

Ryc. 1. Lokalizacja głównych żył rudnych rejonu górniczego Linares - La Carolina; 1 - aluwia , 2 - piaski, zlepieńce i iły, 3 - gliny, piaskowce i wapienie, 4 - gliny i piaskowce, 5 - dolomity i gliny, 6 - zlepieńce, piaski i iły, 7 - łupki, 8 - kwarcyty, 9 - granit, 10 - żyły rudne (wszystkie ilustracje: Colectivo Proyecto Arrayanes) 


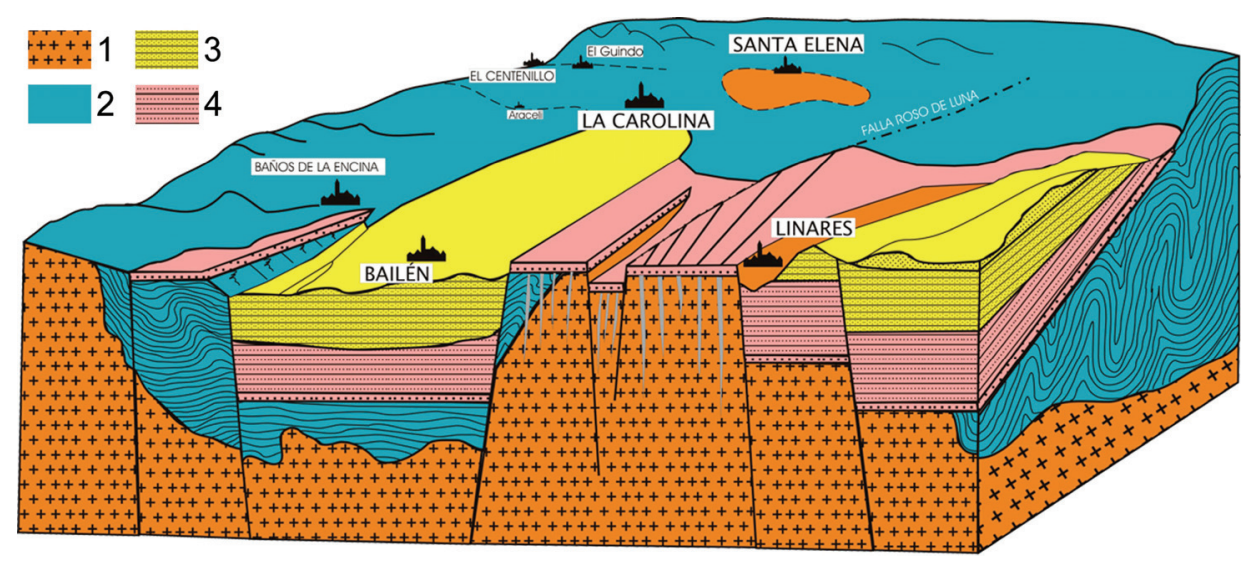

Fig. 2. Geological structure of the Linares - La Carolina mining district; 1 - granite, 2 - slate, 3 - alluvial, 4 - sandstone

Ryc. 2. Budowa geologiczna rejonu górniczego Linares - La Carolina; 1 - granity, 2 - hupki, 3 - aluwia, 4 - piaskowce

\section{History}

Several civilizations have colonised this territory to work the rich mineral veins throughout forty centuries, carrying out an intensive and continuous mining activity that has been essential for the economic and social development of the area. In this way one of the main exceptions of industrialisation was shaped in Andalusia, a region almost entirely oriented to the agricultural and stock activities.

The metals strip mining has been along the history one of the factors of the civilizations development. Specifically, in our district firstly the cooper and later the silver and the lead extraction formed an strategic site in the metals production, internationally recognised in all the ages.

Throughout the Bronze Age, the Argaric culture colonised our territory to work numerous cooper mines and establishing many settlements for the bronze metallurgical manufacture (Dueñas Molina et al., 2004). The settlement of Peñalosa (Fig. 3) is one of the most important remains from that period, due to the urban planning as well as to its situation in a unique mining area (Contreras Cortes \& Dueñas Molina, 2010). Later, Romans and Carthaginian fight for the control of the silver and lead mining, that was initiated by the Iberians. The Romans established several mining works, in the mining fields around Linares (including Arrayanes and La Cruz), as well as in the Sierra Morena (El Centenillo and Salas de Galiarda), where mining and metallurgical activity was very intensive and evidence of well-preserved Archimedes screws were discovered in 1911 (Fig. 4). 


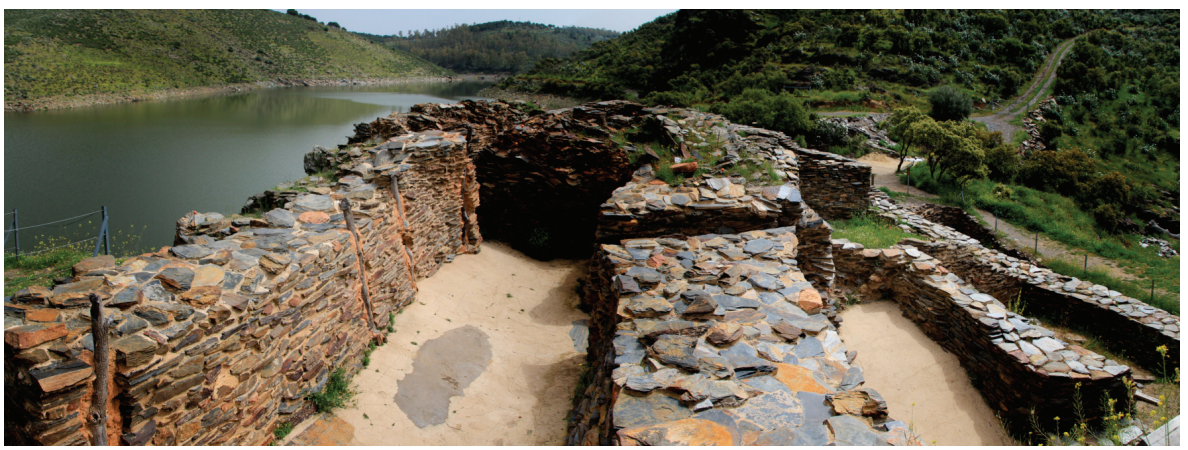

Fig. 3. The Argarica settlement of Peñalosa, in Baños de la Encina was one of the most important of the Oretania region Ryc. 3. Osada argariańska Peñalosa w Baños de la Encina była jedną z najważniejszych regionu Oretanii

Fig. 4. Roman workings in a vein at Cerro Hueco Mine, in Guarromán Ryc. 4. Rzymskie wyrobiska w obrębie rudnej żyły kopalni Cerro Hueco w Guarromán

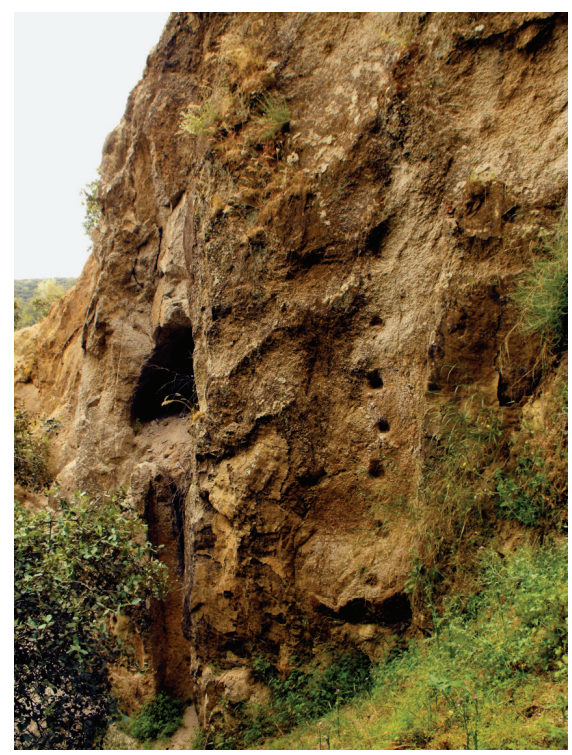

Registries dating from 1563, referred to mining concessions in the area, pointing to continued mineral exploitation in the Middle Ages and Moorish domination. In 1749 the Spanish Crown took an interest in the district and intervened in the lead production establishing the Arrayanes Mine. Mining assumed a new and important impulse attracting many technicians and specialised workers from the Almaden Mines.

But was in the 19th Century, with the second industrial revolution, when the lead mining acquired an international recognition and many foreign mining companies (British, French, German, Belgian) invested in our mining (Thomas, 
1857), making our district into the main producer of lead in the world in 1867 , with great influence in the international lead prices (Mesa, 1889-1890; Fig. 5).

The industrial infrastructure and the transport developed under the shelter of the mining were and unique example in the 19th and 20th centuries. Five railway stations coexisted in only a city (Linares) and several railway lines connected the mining sites of the district between them and with other regions in the east, centre and south of the peninsula. Several aerial rope lines, mainly in places difficult to access, connected the mines with the numerous smelting works installed in Linares, La Carolina and Guarromán to complete the metallurgical process. Also, many different industries were established taking advantage of the mining activity and the area became in a prominent industrial enclave in the south of Spain (Artillo González, 1987b).

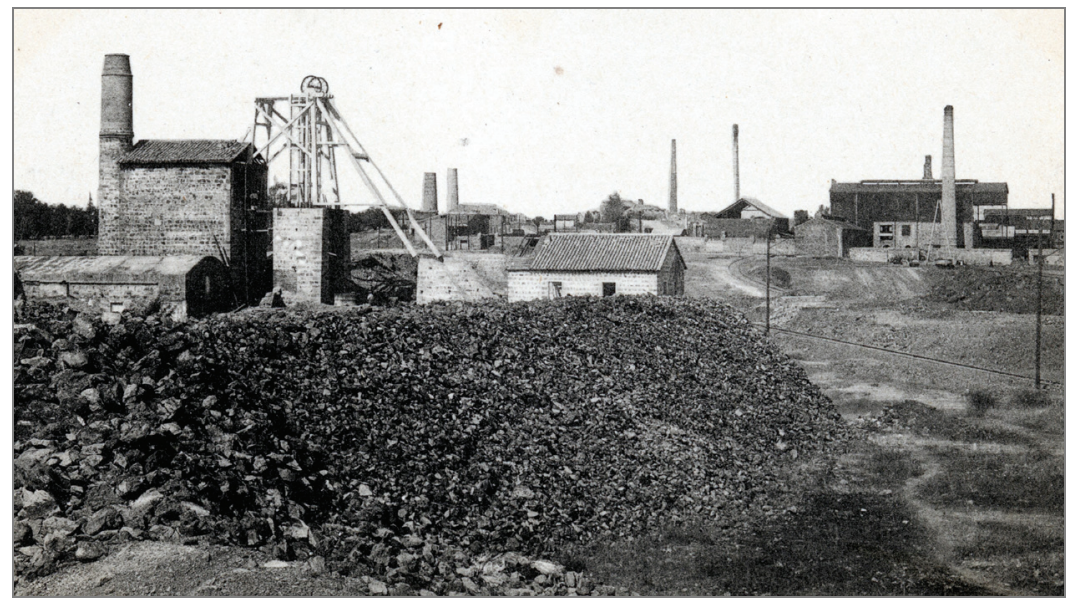

Fig. 5. La Union shaft at La Cruz Mining and Smelting installations, Linares Ryc. 5. Szyb La Union w zakładach górniczo-hutniczych La Cruz w Linares

\section{Society and mining culture}

The arriving of the first pumping steam engine from Cornwall, U.K., in 1849 was the start of an accelerated implementation of the second industrial revolution, that here was, really, the only one. This gave rise to the setting-up of a society with global value industrial examples, coinciding with social organisations typical of the industrialisation including configuration of large capitals, establishing of big banks, publishing of numerous local newspapers, spectacular population increasing and cities growing. Four countries established their consulates in Linares, while new ways of coexistence and customs were binding 
characteristics from several origin together, and formed the identity of this territory (Artillo González, 1987a).

In moments of the bigger mining splendour, miners from several Spanish regions came to the district, as well as technicians and business owners from other countries, forming a multicultural and cosmopolitan community integrating the most diverse cultural elements that gave rise to a rich intangible cultural heritage (Rose, 1875).

Each group, including the British that in other places was inclined to live isolated, was mixing up with the others preserving the characteristic elements (typical clothing, popular culture expressions or the existence of the English Cemetery). A custom framework was being developed around the culture generated by the miner life. In this way, a society that lived with happiness the mining successes and suffered its failures was growing, a population that even today has a way of life, feel and think related with the mine.

\section{Inherited elements}

In an extension so small as our district, we find a large concentration of settlements and elements that in turn present a great historical and typological diversity. According to the age, numbers of remains are following: prehistory - 98, ancient -232 , medieval -49 , modern - 34, industrial - 1618 , undetermined -50 . The architectonic, structural and industrial most significant elements of the district heritage catalogued until now are given below:

Table 1. Variability and number of significant elements of mining heritage in the Linares - La Carolina district

Tabela 1. Zróżnicowanie i liczba istotnych elementów dziedzictwa górniczego obszaru Linares - La Carolina

\begin{tabular}{|c|c|c|c|}
\hline $\begin{array}{l}\text { Type of element / } \\
\text { Rodzaj obiektu }\end{array}$ & $\begin{array}{c}\text { Number/ } \\
\text { Liczba }\end{array}$ & $\begin{array}{l}\text { Type of element / } \\
\text { Rodzaj obiektu }\end{array}$ & $\begin{array}{c}\text { Number/ } \\
\text { Liczba }\end{array}$ \\
\hline $\begin{array}{l}\text { Bronze age settlements / Osady } \\
\text { epoki brąu }\end{array}$ & ' & Chimneys / Kominy & 150 \\
\hline $\begin{array}{l}\text { Roman mining sites / Rzymskie } \\
\text { stanowiska eksploatacji }\end{array}$ & 38 & $\begin{array}{l}\text { Stone headgears / Kamienne wieże } \\
\text { szybowe }\end{array}$ & 27 \\
\hline $\begin{array}{l}\text { Horse whim platforms / Platformy } \\
\text { kruszarni konnych (kieratów) }\end{array}$ & 20 & $\begin{array}{l}\text { Iron headgears / Żelazne wieże } \\
\text { szybowe }\end{array}$ & 21 \\
\hline Whim engine houses / Kruszarnie & 8 & $\begin{array}{l}\text { Bull engine house / } \\
\text { Maszynownie z silnikiem typu ,Bull”, }\end{array}$ & 1 \\
\hline $\begin{array}{l}\text { Cornish pumping engine houses / } \\
\text { Pompownie typu kornijskiego }\end{array}$ & 36 & Electrical power stations / Elektrownie & 54 \\
\hline Boiler houses / Kotłownie & 92 & $\begin{array}{l}\text { Shot towers and foundries / Wieże do } \\
\text { produkcji śrutu i huty }\end{array}$ & $5-8$ \\
\hline $\begin{array}{l}\text { Winding engine houses / } \\
\text { Maszynownie wyciagowe }\end{array}$ & 260 & $\begin{array}{l}\text { Ore dressing floors / Miejsca przeróbki } \\
\text { rudy }\end{array}$ & 54 \\
\hline
\end{tabular}


In addition to these remains an important combination related with the mining activity are preserved. So, a dense transport lines framework connecting the mines and the metallurgical installations with the towns stand out, as roads, railway lines, aerial rope lines or tram lines.

Also, we have significant examples of isolated mining settlements, as well as mining housing and neighbourhood in the cities, together with a singular example of single barracks, located in El Centenillo settlement, which has almost three thousand inhabitants (Caride Lorente, 1978).

\section{Legal protection}

So extensive heritage is yielded to many risks, from the usual with origin in the surrounding human activities, to the cruel plundering suffered by all the mining and metallurgical installations. The damage produced by the time make all this situation worse.

One of the objectives included in the Proyecto Arrayanes, document around which was formed in 1998 with the same name of the Colectivo, is the legal protection of our inherited elements. In this way, the Culture ministry of the Junta de Andalusia entrusted our association the research to identify the most significant remains catalogue. The result was the inclusion in the Andalusia Historic Heritage List of 65 mining and metallurgical and archaeological sites, that was published in January 2004. By a new request of the General Direction of Cultural Goods of the Junta de Andalusia, we extended the catalogue with a second expedient to include in the List 60 new sites, inscribed on 16th October 2006.

We have worked in the individual protection for some significant remains, obtaining the declaration as Cultural Good for the Argaric Settlement of Peñalosa in Baños de la Encina (2009) and for the mining and metallurgical installations of La Tortilla in Linares (2012) (Fig. 6).

But all this is not sufficient because the significance of the district heritage and the diversity of risks threatening to it. Although, since the Historical Heritage Law of Andalusia was published in 2007, a new way to obtain an appropriate level of protection for an extensive heritage like ours is open. In the article 26.8 the Heritage Areas are defined as: "those territories or spaces forming an inherited combination, diverse and complementary, integrated by diachronic goods representative of the human evolution, that have a value for the use and benefit for the community and, in this case, environmental and landscape values". 


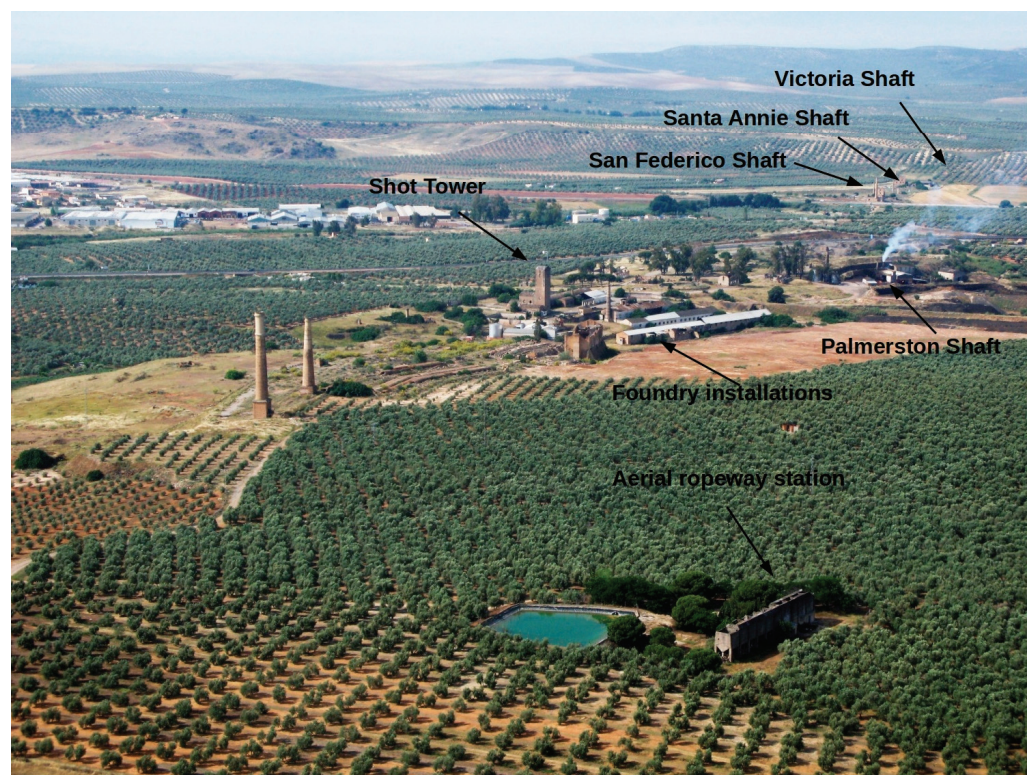

Fig. 6. Aerial view of La Tortilla mining and metallurgical installations included in the declaration as Cultural Ryc. 6. Zdjęcie lotnicze zakładów górniczo-hutniczych La Tortilla ujętych w deklaracji jako Dobro Kulturowe

As this legal figure is appropriate for the characteristics and possibilities of inscription as inherited combination of the district, the Colectivo is currently preparing the documentation to apply the declaration as Heritage Area. This figure provide advantages over the generic catalogue of 125 elements, as well allows a certain level of management for the remains.

- Provides an higher legal protection level for all the remains, including not only the sites and remains, but also the roads, railway lines, natural environment, etc. In addition this protection obtain the territory coordination.

- Allows to increase the number of protected goods and strengthen the idea of ensemble. The declaration as Heritage Area is not only an aim, must be the resource to unify and get common identity to the district communities: programming activities as routes, games, talks, educational exchanges; celebrating Santa Barbara's day as the district festivity; using a common logo.

- Makes possible to increase the protection measure over the territory.

- Gives coherence to the coexistence of remains from several eras.

- Protect the specific characteristics of the mining landscape. 
- Gives rise to a typical management way using the figure of Cultural Park, allowing the basis of a common work in which all us are active part of the project.

- Improves the position of the district in face to ICOMOS (International Council of Sites and Monuments), UNESCO consultative organisation, to obtain the declaration as World Heritage Site. In this way we have progressed with the inclusion of our mining and metallurgical heritage in the Spanish indicative list in 2007 (C.P.A., 2006).

- Locates the district in the most important global circuits of sustainable tourism, being on a level with other nearby sites as Úbeda and Baeza Renaissance Towns or the Natural Park of Cazorla, Segura and Las Villas.

- Invigorates socio-economically a territory strongly punished by the loss of our industrial tradition.

- Creates a common identity for the district: eight municipalities and one Heritage Zone, with common, revisable and coherent criteria for the management, proposed from the own district.

To develop this legal figure in an extensive territory like this, we have marked out 16 sectors. Each one is assembled around one or several main veins. These veins are the geological element origin of the mineral deposits and have characteristics that make easy their study and research as well as the cataloguing of the associated elements.

- To define the mining activity inherited elements concentration.

- To extend and put it together, giving rise to connections by several type of roads, establishing relationship with other human activities and, ended, giving continuity to de remains alignment by different municipalities.

- They leaved the extraction activities mark in the natural environment and content the proofs of how this has integrated.

Each sector includes mining sites, remains related with the ore dressing and metallurgical installations, transport routes, mining villages, as well as archaeological sites. Some of them includes only a main vein, of great importance and with a unity of exploitation throughout the time. Others include several veins, almost parallel, worked by the same companies or with similar technological resources in the same historical periods. Finally, others cover more complex veins systems, especially in the northwester area, that were worked together.

Several veins lay out throw several municipalities, linking the different remains and showing the idea of the unity of the district, essential to understand the importance of the mining activity along the time. The veins, as the mining, are not fixed to administrative territorial divisions. 


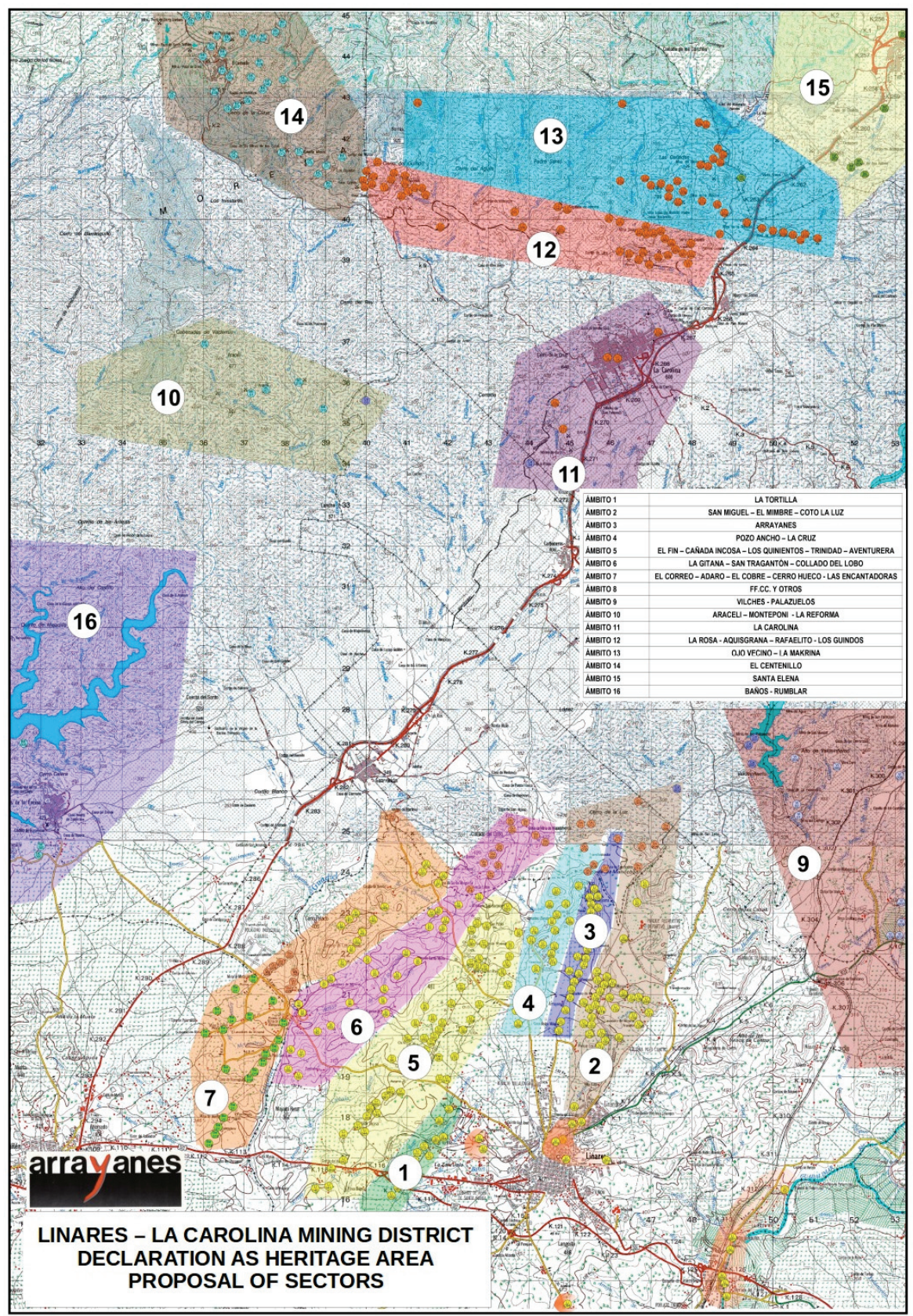

Fig. 7. Initial proposal of sectors for the declaration of Linares - La Carolina mining district as Heritage Area Ryc. 7. Wstępna propozycja obszarów do deklaracji rejonu górniczego Linares - La Carolina jako Obszaru Dziedzictwa 
In the illustration we can see the remains alignment along the veins direction. Each sector is identified by a colour, as well as the sites of each municipality (Fig. 7).

To define each sector we have taken in account a series of common factors, giving them coherence and identity, as follows.

- History and mining culture. Taking into account the mining works throughout the time, the national and foreign mining companies involved in it, the evolution of the technological resources used, the settlement and characteristics of mining culture and work and the evolution of the of the land and mines property.

- Territory. The types of ground and geographical elements define a cohesion that, in addition to the existence of roads and communication lines, must be taken in account in order to the urban and territorial norms adaptation.

- Landscape and environment. The mining activity gave rise to a landscape typology, as result of the interaction with other human surrounding activities. It is essential the characteristic identification to establish landscape management proposals.

- Environment. Nature has integrated the traces of the mining, giving rise to an specific flora and fauna, with a special way of water presence, and the expression in surface of the geodiversity causing each vein.

- Mining typology. Each vein was worked using specific technological elements and left interrelated remains of industrial architecture, shown the mining activities dimensions.

- Security risks. The underground works could provoke surface risks that is necessary to know. In addition to the pressure of other activities, must be taken in account to know the danger of environmental damages and the necessity of mining wastes management.

- Cartography. Each sector must be identified by plans and aerial photographs explain the morphology and the location of all the elements included (Fig. 8).

- Remains summary. A catalogue of mining - metallurgical and archaeological sites is essential to identify what we will protect and the protection level we will apply. So, it is necessary to carry out registry cards identifying each one.

All this is summarised in the following scheme, that is orienting the work (Fig. 9). 


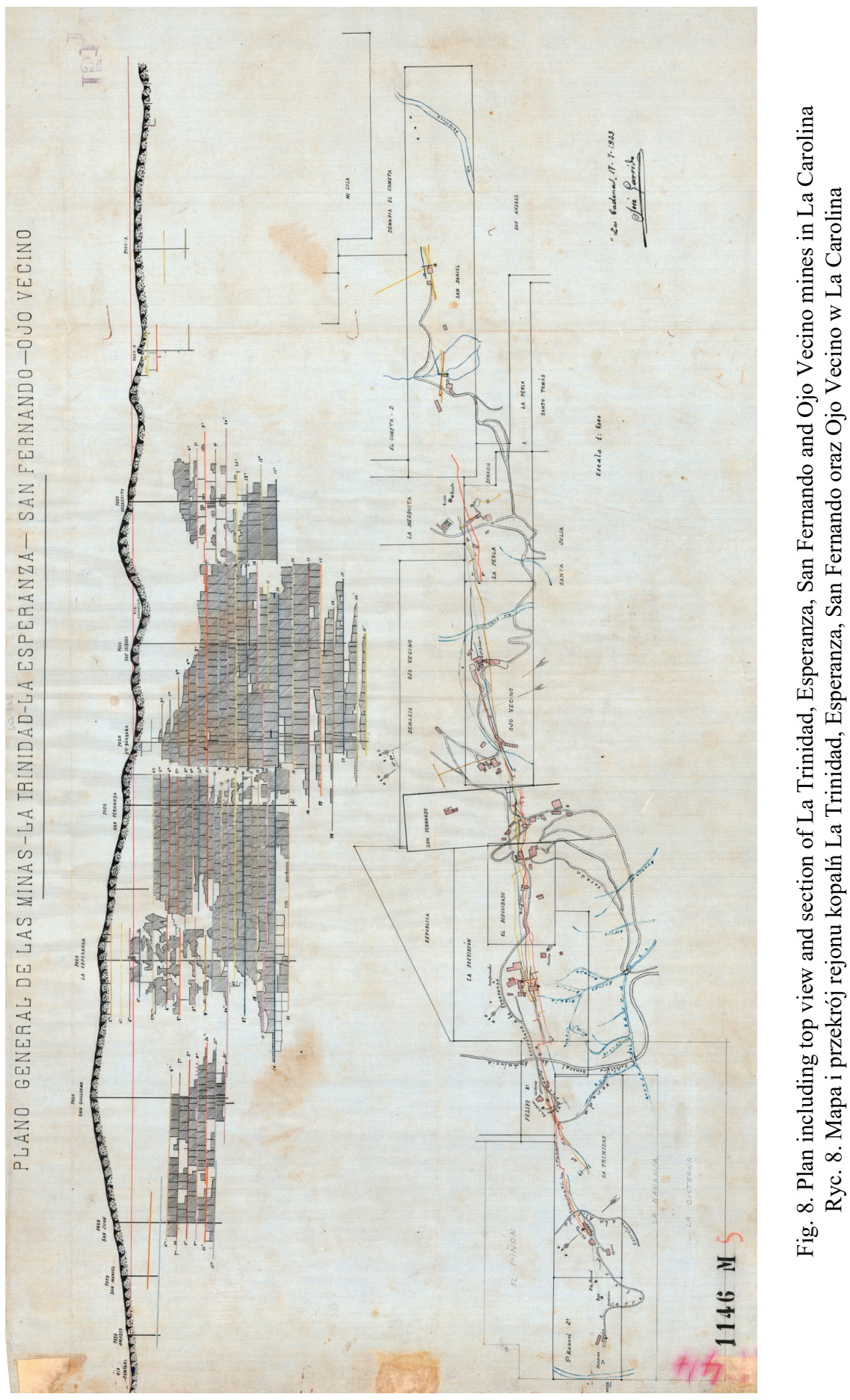




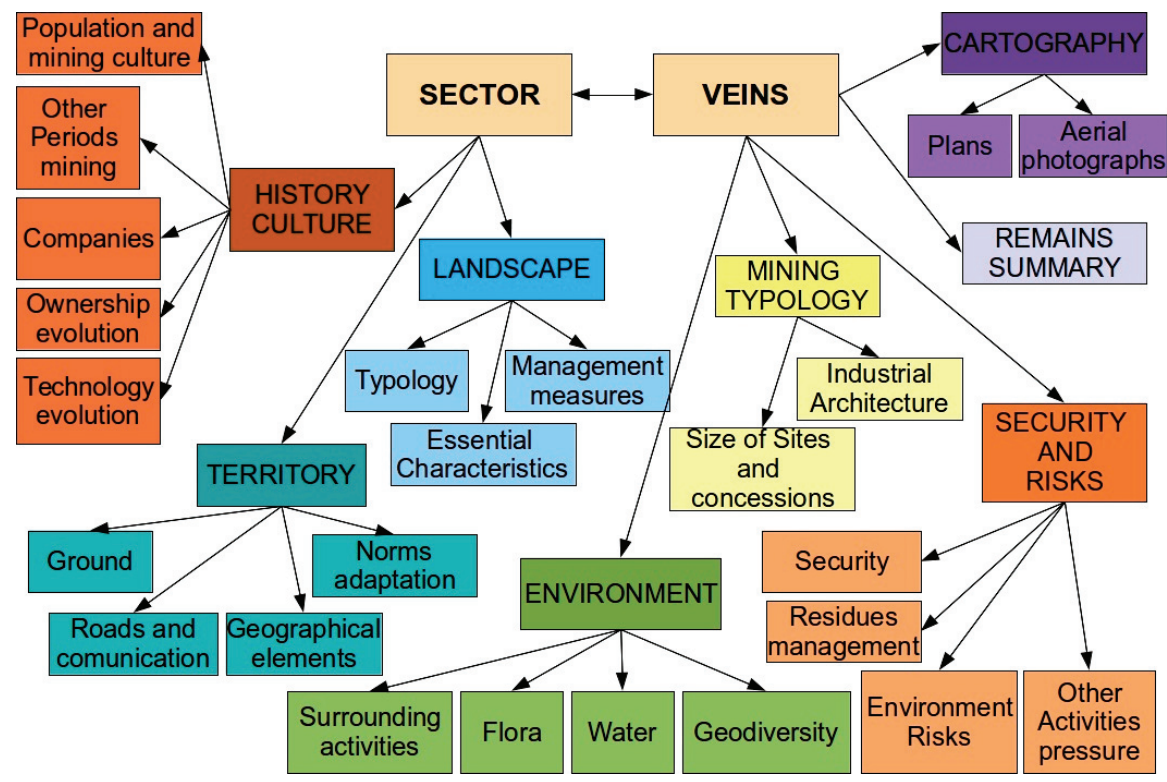

Fig. 9. Working scheme of Heritage Area Project Ryc. 9. Roboczy schemat Projektu Obszaru Dziedzictwa

\section{Design of the Heritage Area Methodology}

The Colectivo Proyecto Arrayanes is working during the last years on this project. The catalogue has jet more than 580 registry cards that includes different identification, elements (pumping engine house, Cornish house, winding engine house, chimney, water reservoir, shaft, head frame, ore dressing, railway station, furnaces, etc.), geographical situation, a brief description of the history and technology applied, some photographs (ancients and news), state of preservation, singularity and bibliographic references. All this information is managed by a spread sheet (Fig. 10).

On the other hand, the Strategic Plan of the Diputación de Jaén for the period 2014-2020, includes the establishment of a Cultural Park in Linares: "The objective is to obtain the declaration as Heritage Area in the municipality of Linares, in order to create a Cultural Park implying the start of an institution to design strategies related with the preservation and valuation of the industrial heritage of Linares. The Cultural Park would be held by the Archaeological Set of Cástulo, the future Industrial Heritage Area, as well as Archaeological sites as Peñalosa historical settlement, in Baños de la Encina, and other heritage sites of the area, to contribute to the sustainable tourism operating of this resource". 
To complete the catalogue a systematic field work is being done, following the veins to identify and register all the elements of interest. To do this we are consulting different available sources, as the Provincial Historical Archive of Jaén, Cartography of La Cruz company, documentation from the Peñarroya Archive, Mining Statistics of Spain, Spanish Mining Journal, digital newspapers and periodicals library, local newspapers, Rob Vernon publications about British companies working in the district (Vernon, 2013), as well as documentation from the own Colectivo Proyecto Arrayanes (2005; 2006; 2013a; 2013b; 2014; Campos López et al., 2004).

Simultaneously, the administrations should collect information about the sites and lands ownership, as well as the property of the roads. Fortunately, it is usual to have easy access to the sites, in spite of the majority of the inherited elements are into private properties.

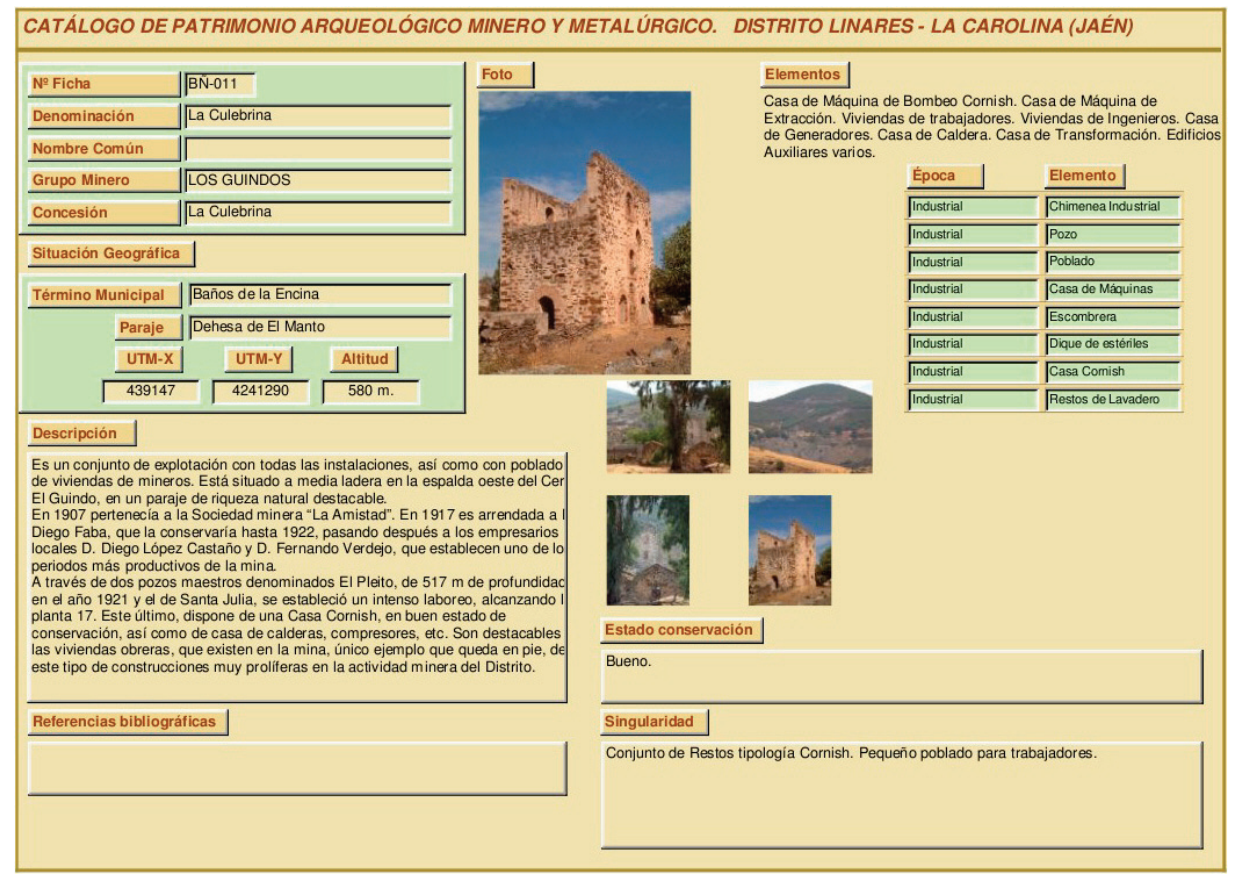

Fig. 10. Example of the registry card for sites included in the Heritage Area Ryc. 10. Przykład karty katalogowej stanowiska włączonego w Obszar Dziedzictwa

The eight municipalities included in the district were informed of the previous works and asked for support, that all of them confirmed by plenary session agreements. From this moment, a working group was formed with representatives from these municipalities and from some other associations. To develop 
the work we are maintaining periodic meetings to elaborate the documentation necessary for the initiation of the expedient for the declaration as Heritage Area of the ancient Linares - La Carolina mining district. Currently we are forming a formal association as legal figure for the working group.

Some months ago we held a meeting with the Authorities of Culture of Junta de Andalucía in Jaén, responsible of the expedient processing, to inform about our intention and the work carried out until today. The idea was well received and we agree some details about the form and extension of several sectors, and the particular requirements for the use of the land affected for the declaration.

Very soon, we will develop a campaign of support and joining to the project, focussed to institutions, companies, associations, etc., of the area. Currently we have the support of the University of Jaén, the Chartered Institutes of Mining Engineers of Linares and Architects of Jaén, and other mining associations as ACMICA from La Carolina.

We are using the application Google Earth for the graphic definition of the sectors, because its broad and easy use. Over this format we are shaping the different protection levels around the mining sites. The first one, reduced and close-fitting to the remains with the higher protection. A second one, including several elements and with a lower protection, represent a security perimeter laying out over the underground veins (Fig. 11).

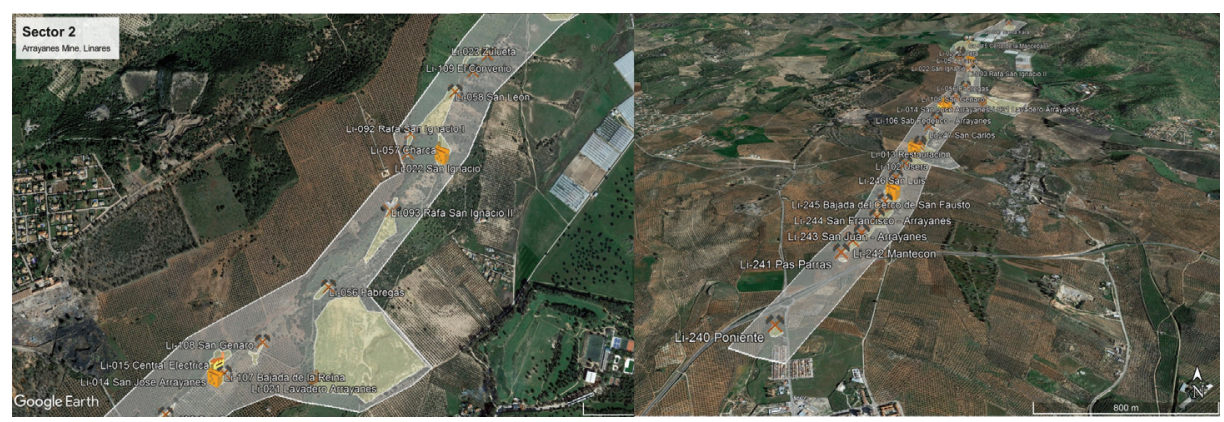

Fig. 11. Detail and aerial view of the Sector 2 definition Ryc. 11. Szczegóły na zdjęciu lotniczym Sektora 2

We are preparing specific requirements for each one of these areas, defining the activities could be carried out inside it. Inside the polygon around each remain the activities should be limited by the preservation and the final definition of the protection polygons must establish a balance between both the heritage and the economic interest. The majority of the sites are located in private ownerships, and the protection should not be a disadvantage for the economic development. This balance is a fascinating challenge, as enough owners appreciate the mining remains persisting into their properties. 
Usually, the activities carried out in the mining fields are mainly agricultural, hunting and stock. In many cases they are being compatible with the heritage preservation, and must stay the same. For example, the wild livestock was a basic way to preserve some inherited elements. Probably the most harmful activities are those agricultural related with the olive grove, as sometimes the increase of cultivable extension caused the loss of mining buildings and even shafts. Also, the wastes exploitation to obtain sand and gravel for construction and public works, has been very harmful provoking risks and destroying buildings in the mining sites.

With the legal protection we want prevent the misappropriation or closing of ancient mining roads, allowing the access to the protected remains in the terms established in the law. In the same way, the heritage area declaration will prevent the plundering of mining elements, maintaining the security improvement works and preserving the wastes as inherited elements.

\section{Literature}

ANONIMOUS, 1877. Estudio geológico industrial de los filones de galena de la Mesa granítica de Linares, provincia de Jaén. Linares.

ARTILLO GONZÁLEZ, J., 1987a. El ciclo inicial de la minería linarense en la época contemporánea (1750-1860). [In:] La Minería de Linares (1860-1923). Diputación de Jaén y Ayuntamiento de Linares. Jaén: 15-35.

ARTILLO GONZÁLEZ, J., 1987b. Problemas y dificultades de comercialización: finanzas y transportes. [In:] La Minería de Linares (1860-1923). Diputación de Jaén y Ayuntamiento de Linares. Jaén: 85-116.

CAMPOS LÓPEZ D., PÉREZ SÁNCHEZ A.A., DUEÑAS MOLINA J., GÓMEZ GONZÁLEZ M., CONTRERAS CORTÉS F., GARCÍA SOLANO J.A., ARBOLEDAS MARTÍNEZ, L., 2004. PR-A 260. Un ejemplo de puesta en valor. [In:] Puche Riart O. (ed.). Minería y metalurgia históricas en el sudoeste europeo. Madrid: 621-629.

CARIDE LORENTE C., 1978. Historia de las Minas del Centenillo. C.O. I, de Minas de Levante. Madrid.

COLECTIVO PROYECTO ARRAYANES /ale wszystkie - w tekście są czasem odwołania do COLECTIVO PROYECTO ARRAYANES, ale bez lat, a to są przecież różne dokumenty/, 2005. Sendero de Paño Pico. PR-A 260. Linares.

COLECTIVO PROYECTO ARRAYANES, 2006. Distrito Minero Linares - La Carolina. Documento de propuesta para la denominación como Patrimonio de la Humanidad. Linares.

COLECTIVO PROYECTO ARRAYANES, 2013a. Sendero de El Cerro de las Mancebas. PR-A 261. Linares.

COLECTIVO PROYECTO ARRAYANES, 2013b. Sendero de La Garza y San Andrés. PR-A 262. Linares.

COLECTIVO PROYECTO ARRAYANES, 2014. Sendero de la mina de La Gitana. PR-A 264. Linares.

CONTRERAS CORTES F., DUEÑAS MOLINA J., 2010. La minería y la metalurgia en el Alto Guadalquivir: desde sus orígenes hasta nuestros días. Instituto de Estudios Giennenses, Diputación Provincial de Jaén. Jaén. 
José Dueñas Molina et al.

HEREZA J., ALVARADO A., 1926. The metalliferous deposits of Linares and Huelva. Instituto Geológico de España. Madrid. 36.

IGME, 1977. Mapa geológico de España, Linares 905. Instituto Geológico Minero de España. Madrid.

IGME, 1976. Mapa geológico de España, La Carolina 884. Instituto Geológico Minero de España. Madrid.

MESA Y ÁLVAREZ P. de, 1889-1890. Memoria sobre la zona minera Linares - La Carolina. Revista Minera, Metalúrgica y de Ingeniería. Madrid.

MOLINA DUEÑAS J., CONTRERAS CORTÉS F., MORENO ONORATO A., JARAMILLO JUSTINICO A., GARCÍA SOLANO J.A., ARBOLEDAS MARTÍNEZ L., CAMPOS LÓPEZ D., 2004. Estudio de la minería industrial en la cuenca del Rumblar. [In:] Puche Riart O. (ed.), Minería y metalurgia históricas en el sudoeste europeo. Madrid: 475-487.

ROSE H. J., 1875. Untrodden Spain and her Black Country. London.

THOMAS J. Lee, 1857. Notes of the Lead-Mining District of Linares. London.

VERNON R.W., 2013. Thomas Sopwith Jr., British Mining, No. 95. Nelson, Lancashire.

\section{ZNACZENIE ŻYL RUDNYCH DLA STUDIOWANIA, INTERPRETACJI I OCHRONY DZIEDZICTWA GÓRNICZEGO}

dziedzictwo górnicze, ochrona prawna, krajobraz kulturowy, metodologia pracy

Cztery tysiące lat działalności górniczej ukształtowało na obszarze Linares-La Carolina swoisty krajobraz kulturowy. Geologiczne bogactwo tego obszaru interesowało główne cywilizacje wszystkich epok. Argarianie, Rzymianie, Kartagińczycy, podobnie jak później wielkie kompanie górnicze z Wielkiej Brytanii, Niemiec, Francji i Belgii w okresie przemysłowym, wszyscy wznosili swoje zakłady pracujące funkcjonujące na bogatych żyłach miedzi i ołowiu.

W 2002 r. władze ds. kultury Zarządu Andaluzji powierzyły stowarzyszeniu Colectivo Proyecto Arrayanes wykonanie inwentaryzacji najważniejszych pozostałości górniczych. Rezultatem wykonanej pracy była dokumentacja obejmująca 65 stanowisk górniczych i hutniczych z Listy Andaluzyjskiego Dziedzictwa Historycznego. Później badania poszerzono o drugi zapis kolejnych 60 stanowisk, należących do wszystkich gmin tego górniczego obszaru.

Obecnie Stowarzyszenie opracowuje projekt mający na celu deklarację tego dawnego rejonu górniczego jako Obszar Dziedzictwa, nową postać prawną Dziedzictwa Historycznego stworzoną w Andaluzji w 2007 r. Mogłoby to zapewnić lepszy poziom ochrony głównej części terenów górniczych, ale też pozostałego obszaru, w tym stanowisk archeologicznych. Deklaracja taka umożliwiłaby zarządzanie tym terytorium jako Parkiem Kultury.

Przedstawiona propozycja ustanawia 16 obszarów, poszerzonych o osiem gmin. Każdy obszar związany jest z jedną lub kilkoma żyłami rudnymi i obejmuje stanowiska górnicze, archeologiczne oraz pozostałości związane z metalurgią, przeróbką rudy i obiekty kolejowe. Każde stanowisko opisane jest w formie oddzielnej karty kartoteki rejestru. Stworzony katalog obejmuje ponad 560 stanowisk, z których około 150 posiada dowody wykorzystywania technologii kornwalijskiej.

Krajobraz kulturowy oraz rudne żyły stanowią oś przyszłego rozwoju terytorium górniczego. Pozostałości przemysłowe i górnicze, drogi, linie kolejowe itp., są umieszczone w stosunku do orientacji żyły. Właśnie one są głównymi wytycznymi do stworzenia roboczej metodologii, opracowywanej w celu ukończenia tego ambitnego projektu. 